\title{
Editorial: Remote Sensing for Aquaculture
}

\author{
Pierre Gernez ${ }^{1 *}$, Stephanie C. J. Palmer ${ }^{1}$, Yoann Thomas ${ }^{2}$ and Rodney Forster ${ }^{3}$ \\ ${ }^{1}$ University of Nantes, Mer Molécules Santé, Nantes, France, ${ }^{2}$ IRD, University of Brest, CNRS, Ifremer, LEMAR, Plouzané, \\ France, ${ }^{3}$ Hull Marine Laboratory, Department of Biological and Marine Sciences, University of Hull, Hull, United Kingdom
}

Keywords: earth observation, site selection, HAB risk assessment, production monitoring, ecological modeling, kelp, fish, shellfish

\section{Editorial on the Research Topic}

Remote Sensing for Aquaculture

While the sustainability of aquaculture is crucial for global food security, aquaculture development faces major threats and challenges, such as the increasing competition for land, water, and energy resources, as well as vulnerability to global warming, sea level rise, water pollution, increased occurrence of extreme events, harmful algal blooms (HABs), and disease outbreaks (Froehlich et al., 2018; Soto et al., 2019). Compared to land-based aquaculture where suitable areas are limited by space constraints, there is immense potential for the expansion of aquaculture in the coastal and open oceans (Gentry et al., 2017). The intensification of marine aquaculture, if not managed properly, could, however, lead to serious environmental impacts and socio-economic conflicts, and there is a clear need for ecosystem-based approaches to aquaculture planning in the marine realm (Lester et al., 2018).

In the ocean, most aquaculture species, equipment, and operations are sensitive to the variability of environmental parameters, such as sea surface temperature (SST), currents, wave height, underwater irradiance, and/or water quality in terms of suspended particulate matter (SPM) and phytoplankton. All of these parameters are highly variable over time and space, adding to the complexity of planning and management. Due to its ability to map essential variables at multiple scales and resolutions, Earth Observation (EO) can help to comprehensively optimize aquaculture location and type in both the nearshore and offshore oceans (Meaden and Aguilar-Manjarrez, 2013). Spatially-explicit time-series of remotely-sensed parameters have been used for site selection of fish (IOCCG, 2009), shellfish (Saitoh et al., 2011; Thomas et al., 2011; Gernez et al., 2014; Snyder et al., 2017), and kelp aquaculture (Radiarta et al., 2010). Remote sensing can also contribute to aquaculture planning, with the integration of EO into Geographic Information Systems (GIS) (Falconer et al., 2020) and spatial multi-criteria evaluation (SMCE) methodologies to resolve complex environmental and socioeconomic constraints (Kapetsky and Aguilar-Manjarrez, 2007; Radiarta et al., 2008; Brigolin et al., 2017; Barillé et al., 2020). Besides site-selection and planning, aquaculture could also benefit from EO for water quality monitoring (Gernez et al., 2017; SorianoGonzález et al., 2019), notably in the case of HAB detection (Gokul et al., 2020; Rodríguez-Benito et al., 2020; Torres Palenzuela et al., 2020), assessment of fish farming environmental impact (Bengil and Bizel, 2014), and modeling of species invasion associated with aquaculture (Thomas et al., 2016).

The objectives of this Research Topic were to assess the use of advanced EO products over a variety of scales and resolutions, and to document the latest developments in coupling EO with biological and ecological models applied to a variety of aquaculture contexts. All articles focused on offshore marine aquaculture, with the exception of one article dedicated to nearshore intertidal waters. All types of mariculture were investigated: fish, shellfish, and macroalgae aquaculture. 
Although most articles were based on satellite remote sensing, the use of unmanned aerial vehicle (UAV) was also tackled, and a large range of spatial scales considered. Overall, the articles concerned three types of study: site selection, risk to aquaculture (HABs), and production monitoring.

The use of EO for site suitability and selection was addressed in four articles. In Porporato et al., EO-derived SST data was coupled with an ecophysiological model based on a dynamic energy budget (DEB) and incorporated into a SMCE framework to optimize the design of allocated aquaculture zones for fish farming (European seabass and gilthead seabream) in the Italian offshore waters. In Palmer et al., EO-derived SST, Chlorophyll and SPM concentration were also coupled with DEB modeling for Pacific oyster aquaculture site selection in a French macrotidal bay, demonstrating the potential of strategically selected offshore sites compared to the traditionallyfarmed, albeit less productive, intertidal zone. In Jossart et al., statistical spatial autocorrelation techniques were incorporated into the planning framework, improving upon conventional site selection approaches. Two approaches were demonstrated for northeastern US case studies; one assessing the relative suitability for mussel farming, the other assessing patterns in modeled and remotely-sensed oceanographic data important to aquaculture. High-resolution SST imagery from Landsat-8 was used as a proxy for surface nitrate concentration by Snyder et al., in their study of offshore kelp farm optimal placement.

The Research Topic also documented some of the latest developments in $\mathrm{HAB}$ remote sensing using the new generation of Sentinel-3 satellites. In Smith and Bernard, an indicator to identify the bloom-dominant phytoplankton type was developed for aquaculture risk mitigation. Spectral features in the red and NIR were used to discriminate two types of HABs (high biomass dinoflagellate vs. Pseudo-nitzschia blooms) from other phytoplankton assemblages in South Africa. The red-edge spectral signature of various $\mathrm{HAB}$ types was also documented in Wolny et al., where promising algorithms to detect common marine and estuarine HAB species (Alexandrium monilatum, Karlodinium veneficum, Margalefidinium polykrikoides, and Prorocentrum minimum) were investigated in the Chesapeake Bay (US).

Finally, the performance of several remote-sensing platforms to monitor offshore kelp farming along the eastern Pacific

\section{REFERENCES}

Barillé, L., Le Bris, A., Goulletquer, P., Thomas, Y., Glize, P., Kane, F., et al. (2020). Biological, socio-economic, and administrative opportunities and challenges to moving aquaculture offshore for small French oyster-farming companies. Aquaculture 521:735045. doi: 10.1016/j.aquaculture.2020.735045

Bengil, F., and Bizel, K. C. (2014). Assessing the impact of aquaculture farms using remote sensing: an empirical neural network algorithm for Ildiri Bay, Turkey. Aquacult. Env. Interact. 6, 67-79. doi: 10.3354/aei00115

Brigolin, D., Porporato, E. M. D., Prioli, G., and Pastres, R. (2017). Making space for shellfish farming along the Adriatic coast. ICES J. Mar. Sci. 74, 1540-1551. doi: 10.1093/icesjms/fsx018

Falconer, L., Middelboe, A. L., Kaas, H., Ross, L. G., and Telfer, T. C. (2020). Use of geographic information systems for aquaculture and coastline was compared in Bell et al.: satellite sensors, UAVmounted optical sensors, underwater imagery and sonar scanning. Using field observations and deep learning, this study provided a valuable analysis of strength, weakness, opportunity, and threat for future developments in the monitoring of far-field kelp production.

In summary, this Research Topic compiled some of the latest remote sensing developments for aquaculture. While three types of studies were addressed (site selection, production monitoring, and $\mathrm{HAB}$ remote sensing), there is no doubt that EO could also benefit other aquaculture topics, notably environmental impact assessment. EO-based analyses of land cover changes associated with aquaculture (Proisy et al., 2018) could, for example, be translated to the seascape. Whatever the topic, future developments of innovative EO products (habitat mapping, phytoplankton groups, species identification, particulate organic carbon, or nitrogen content), as well as advances in data processing (process-based modeling approach, deep learning, and big data analysis) are expected to further improve aquaculture studies. Concurrent to such progress, the uptake of EO data by the aquaculture industry, environmental managers, and policy makers will certainly increase as higher temporal and spatial imagery become available, including very high-resolution observations and services from commercial providers.

\section{AUTHOR CONTRIBUTIONS}

PG, SP, YT, and RF organized this Research Topic and wrote the editorial. All authors contributed to the article and approved the submitted version.

\section{FUNDING}

This work has received funding from the European Union's Horizon 2020 research and innovation programme (Grant agreement No. 678396-Tools for Assessment and Planning of Aquaculture Sustainability, No. 776342-DataCube Services for Copernicus, and No. 776348-Commercial service platform for user-relevant coastal water monitoring services based on Earth observation). recommendations for development of spatial tools. Rev. Aquacult. 12, 664-677. doi: 10.1111/raq.12345

Froehlich, H. E., Gentry, R. R., and Halpern, B. S. (2018). Global change in marine aquaculture production potential under climate change. Nat. Ecol. Evol. 2, 1745-1750. doi: 10.1038/s41559-018-0669-1

Gentry, R. R., Froehlich, H. E., Grimm, D., Kareiva, P., Parke, M., Rust, M., et al. (2017). Mapping the global potential for marine aquaculture. Nat. Ecol. Evol. 1, 1317-1324. doi: 10.1038/s41559-017-0257-9

Gernez, P., Barillé, L., Lerouxel, A., Mazeran, C., Lucas, A., and Doxaran, D. (2014). Remote sensing of suspended particulate matter in turbid oyster-farming ecosystems. J. Geophys. Res. Oceans 119, 7277-7294. doi: 10.1002/2014JC010055

Gernez, P., Doxaran, D., and Barillé, L. (2017). Shellfish aquaculture from space: potential of Sentinel 2 to monitor tide-driven changes in turbidity, chlorophyll 
concentration and oyster physiological response at the scale of an oyster farm. Front. Mar. Sci. 4:137. doi: 10.3389/fmars.2017.00137

Gokul, E. A., Raitsos, D. E., Gittings, J. A., and Hoteit, I. (2020). Developing an atlas of harmful algal blooms in the red sea: linkages to local aquaculture. Remote Sens. 12:3695. doi: 10.3390/rs12223695

IOCCG (2009). "Remote sensing in fisheries and aquaculture," in Reports of the International Ocean-Colour Coordinating Group, No. 8, eds M.-H. Forget, V. Stuart, and T. Platt (Dartmouth, NS: IOCCG).

Kapetsky, J. M., and Aguilar-Manjarrez, J. (2007). Geographic Information Systems, Remote Sensing and Mapping for the Development and Management of Marine Aquaculture. Rome: Food and Agriculture Organization, No. 458.

Lester, S. E., Stevens, J. M., Gentry, R. R., Kappel, C. V., Bell, T. W., Costello, C. J., et al. (2018). Marine spatial planning makes room for offshore aquaculture in crowded coastal waters. Nat. Comm. 9:945. doi: 10.1038/s41467-018-03249-1

Meaden, G. J., and Aguilar-Manjarrez, J. (Eds.) (2013). Advances in Geographic Information Systems and Remote Sensing for Fisheries and Aquaculture. Rome: FAO Fisheries and Aquaculture Technical Paper, No. 552.

Proisy, C., Viennois, G., Sidik, F., Andayani, A., Enright, J. A., Guitet, S., et al. (2018). Monitoring mangrove forests after aquaculture abandonment using time series of very high spatial resolution satellite images: a case study from the Perancak estuary, Bali, Indonesia. Mar. Pollut. Bull. 131, 61-71. doi: 10.1016/j.marpolbul.2017.05.056

Radiarta, I. N., Saitoh, S. I., and Miyazono, A. (2008). GIS-based multicriteria evaluation models for identifying suitable sites for Japanese scallop (Mizuhopecten yessoensis) aquaculture in Funka Bay, southwestern Hokkaido Japan. Aquaculture 284, 127-135. doi: 10.1016/j.aquaculture.2008.07.048

Radiarta, I. N., Saitoh, S. I., and Yasui, H. (2010). Aquaculture site selection for Japanese kelp (Laminaria japonica) in southern Hokkaido, Japan, using satellite remote sensing and GIS-based models. ICES J. Mar. Sci. 68, 773-780. doi: 10.1093/icesjms/fsq163

Rodríguez-Benito, C. V., Navarro, G., and Caballero, I. (2020). Using Copernicus Sentinel-2 and Sentinel-3 data to monitor harmful algal blooms in Southern Chile during the COVID-19 lockdown. Mar. Pollut. Bull. 161:111722. doi: 10.1016/j.marpolbul.2020.111722

Saitoh, S. I., Mugo, R., Radiarta, I. N., Asaga, S., Takahashi, F., Hirawake, T., et al. (2011). Some operational uses of satellite remote sensing and marine GIS for sustainable fisheries and aquaculture. ICES J. Mar. Sci. 68, 687-695 doi: 10.1093/icesjms/fsq190
Snyder, J., Boss, E., Weatherbee, R., Thomas, A. C., Brady, D., and Newell, C. (2017). Oyster aquaculture site selection using Landsat 8-Derived Sea surface temperature, turbidity, and chlorophyll a. Front. Mar. Sci. 4:190. doi: 10.3389/fmars.2017.00190

Soriano-González, J., Angelats, E., Fernández-Tejedor, M., Diogene, J., and Alcaraz, C. (2019). First results of phytoplankton spatial dynamics in two NWMediterranean bays from chlorophyll- $a$ estimates using Sentinel 2: potential implications for aquaculture. Remote Sens. 11:1756. doi: 10.3390/rs111 51756

Soto, D., Ross, L. G., Handisyde, N., Bueno, P. B., Beveridge, M. C., Dabbadie, L., et al. (2019). Climate Change and Aquaculture: Vulnerability and Adaptation Options. Rome: Impacts of Climate Change on Fisheries and Aquaculture, FAO Fisheries and Aquaculture Technical Paper No. 627, 465-490.

Thomas, Y., Mazurié, J., Alunno-Bruscia, M., Bacher, C., Bouget, J. F., Gohin, F., et al. (2011). Modelling spatio-temporal variability of Mytilus edulis (L.) growth by forcing a dynamic energy budget model with satellite-derived environmental data. J. Sea Res. 66, 308-317. doi: 10.1016/j.seares.2011. 04.015

Thomas, Y., Pouvreau, S., Alunno-Bruscia, M., Barillé, L., Gohin, F., Bryère, P., and Gernez, P. (2016). Global change and climate-driven invasion of the Pacific oyster (Crassostrea gigas) along European coasts: a bioenergetics modelling approach. J. Biogeogr. 43, 568-579. doi: 10.1111/jbi.12665

Torres Palenzuela, J. M., Vilas, L. G., Bellas Aláez, F. M., and Pazos, Y. (2020). Potential application of the new Sentinel satellites for monitoring of harmful algal blooms in the galician aquaculture. Thalassas 36, 85-93. doi: 10.1007/s41208-019-00180-0

Conflict of Interest: The authors declare that the research was conducted in the absence of any commercial or financial relationships that could be construed as a potential conflict of interest.

Copyright $\odot 2021$ Gernez, Palmer, Thomas and Forster. This is an open-access article distributed under the terms of the Creative Commons Attribution License (CC BY). The use, distribution or reproduction in other forums is permitted, provided the original author(s) and the copyright owner(s) are credited and that the original publication in this journal is cited, in accordance with accepted academic practice. No use, distribution or reproduction is permitted which does not comply with these terms. 